\title{
THE DISCRIMINATION OF WOMEN AS SEEN IN HENDRICK IBSEN'S A DOLL HOUSE
}

\author{
NURAIDA ${ }^{1}$ \\ MAC ADITIAWARMAN ${ }^{2}$ \\ FETRI RENI ${ }^{3}$
}

Volume 1 Nomor 1

JILP

ISSN: 2581-0804

E-ISSN: 2581-1819

\begin{abstract}
Problems in this thesis is about women, because of discrimination against women, there were resistance can be seen from the main character in the play A Doll's House and his struggle to obtain equality between women and men. Because women do not have to live forever under the pressure of men and not women may not work forever and forever no woman should take care of the children and her husband, like the main character Nora who willingly broke the law for the sake of getting the equality between men and women.

This research method is a method of data collection, data analysis methods while the author does a systematic procedure with an understanding of the drama. Engineering data

collection using the technique of qualitativ in finding relevant data with subject and author data analysis techniques using structural engineering by way of analyzing the drama based on the elements that shape it. In analyzing this drama author using psychology approach discusses the human personality which is the theory of Sigmund Freud includes the id, ego, superego man.

Research results from the play A Doll House, the authors have found that the presence of the Suppression of freedom 1) inside the Doll House, 2) the existence of discrimination on the main character Nora in a doll's House, 3) as well as the struggle to be free from discrimination that had befallen him.
\end{abstract}

Keywords : Discrimination, oppression freedom, selfish, and psychological

\begin{abstract}
ABSTRAK
Permasalahan dalam skripsi ini adalah tentang wanita, karena adanya diskriminasi terhadap wanita, terdapat perlawanan dapat dilihat dari tokoh utama didalam drama A Doll House dan perjuangannya untuk mendapatkan kesetaraan derajat antara wanita dan laki-laki. Karena wanita tidak selamanya harus hidup dibawah tekanan laki-laki dan tidak selamanya wanita tidak boleh bekerja dan tidak selamanya wanita harus mengurus anak-anak dan suaminya,

seperti tokoh utama Nora yang rela melanggar hukum demi mendapatkan kesetaraan derajat antara laki-laki dan wanita.

Metode penelitian ini adalah metode pengumpulan data, sedangkan metode analisis data penulis melakukan prosedur sistematis dengan pemahaman drama. Teknik pengumpulan data menggunakan teknik qualitativ dalam mencari data yang relevan dengan subjek dan teknik analisis data penulis menggunakan teknik
\end{abstract}


struktural dengan cara menganalisis drama berdasarkan unsur-unsur yang membentuknya. Di dalam menganalisis drama ini penulis menggunakan pendekatan psikologi yang membahas tentang kepribadian manusia yang merupakan teori dari Sigmund Freud meliputi id, ego, superego manusia.
Hasil penelitian dari drama A Doll House, penulis telah menemukan bahwa 1) Adanya penindasan kebebasan didalam rumah boneka, 2) Adanya diskriminasi pada tokoh utama Nora didalam rumah boneka, 3) Serta berjuang untuk bisa bebas dari diskriminasi yang dialaminya.

Kata Kunci: Diskriminasi, Penindasan kebebasan, Egois, dan psikologis.

\section{BACKGROUND OF THE PROBLEM}

Drama reflects and expresses the life, the social condition in society to represent the community and the era (Wellek and Austine, 1956:110). Literary sources have function as a tool of human inspiration to make people aware the meaning of life and to improve the quality of life. Literature sources are phenomena that occur in community such as family life (Wiyatmi, 2012:42). Describing the element of society that occur toward men and women are quite interesting because it present at the other of life both of them socially and culturally. One of the life problems that becames the source of the literary works is the position of women in society. The writer shows the problems that occur in drama with extrinsic elements. The extrensic side becomes an analysis in this writing, it is an attempt to interpret literature in the light of its social context and its incident, in most cases become a casual explanation constitute discussion of element such as psychology, biography, society, history and ideas. The writer focuses on her researches in analyzing Nora selfish characters who has gender equality between men and women is reflected in the play A Doll House Family (1879).

Significances of the research is to add literary study from A Doll House Drama. Then, the finding in this research is useful as the information whoever interested in understanding literary study that focuses on the main characters. This analysis can become the guidance for next researchers to conduct further analysis. For the students this analysis useful as the information who over interested in understanding literary. Finally, this writing will give the contribution to the English Department students and whoever may be interested in the subject being discussed. In this anaslysis, the study will be focused on the psychological background of the character particularly in the main characters. Talking about the psychology term, Daiches (1990:344) defines that psychology of literature in his book Critical Approaches to Literature as "Psychology. It can help to explain in the creative process in general, it can provide a means of illuminating a writer's work with reference to his life and vice versa, and it can help to elucidates the true meaning of a give text." From this quotation, Daiches emphasizes that the author and his work cannot be separated as they are, in facts, they are related to each other. The life that is described through a literary work is presented. In the text which is a reflection of the characters' psychological behavior in life.

Sigmund Freud (1956:32) psychology expert analysis is divided into the id, the superego, the ego. The Id, the most primitive of the three structures is concerned with instant gratification of basic physical needs and urges, for example, an increases in hunger or thirst should produces an immediate attempt to eat or drink. The superego The ego develops in order to mediate between the unrealistic id and the external real world. It is the decision making component of personality. Ideally the ego works by reason, whereas the id is chaotic and totally unreasonable. The ego operates according to the reality principle, working out realistic ways of satisfying the id's demands, often compromising or postponing satisfaction to avoid negative consequences of society. The superego incorporates the values and morals of society which are learned from one's parents and others. The superego's function is to control the id's impulses, especially those which society forbids, such as sex and aggression. It also has the function of persuading the ego to turn to moralistic goals rather than simply realistic ones and to strive for perfection.

In the psychological analysis Sigmund Freud (1956:74-79), psychological approach is 
based on the assumption that literary work always talks about human life events because it concerns about people and their lives, it must contain psychological aspects in the story. Psychology is expected to help us to know the characters well. The general concept of this approach can be seen in the following ideas: 1 . Literary work is the process of subconscious to conscious, 2. Creation process, 3. Meaning, thought, and philosophy, 4. A good work has symbols, 5. Psychological conflict, 6. Self actualization. In this analysis, the concept of psychological conflict and sentimentalization will be applied because in psychological science one learns about behavior and mental process of a person. Wellek and Austin (1956:81) in Theory of Literature who state that "by psychology of literature, we may mean psychological study of the writer a type and individual, or the study of the psychological types and laws present within works of literature."

Sigmund Freud (1956:82) explored the human mind more thoroughly than any other who became before him. His contributions to psychology are vast. Freud was one of the most influential people of the twentieth century and his enduring legacy has influenced not only psychology, but art literature and even the way people bring up their children.Freud's lexicon has become embedded within the vocabularies of western society. Words he introduced thought his theories are now used by everyday people, such as anal (personality), libido, denial, repression, cathartic, Freudian slip, and neurotic. Psychoanalysis is often known as the talking cure. Typically Freud would encourage his patient to talk freely (on his famous couch) regarding their symptoms and to describe exactly what has in their mind. The most significant region is the unconscious. Here lie the processes that are the real cause of most behavior. Like an iceberg, the most important part of the mind is the part you cannot see. The unconscious mind acts as a repository, a 'cauldron' of primitive wishes a nd impulse kept at bay and mediated by the precociousness area. For example, Freud found that some events and desires were often too frightening or painful for his patients to acknowledge, and believed such information was locked away in the unconscious mind. This can happen through the process of repression.

Sigmund Freud (1956:42) emphasized the importance of the unconscious mind, and a primary assumption of Freudian theory is that the unconscious mind governs behavior to a greater degree than people suspect. Indeed, the goal of psychoanalysis is to make the unconscious conscious. The Psyche Freud later developed a more structural model of the mind comprising the entities id, ego and superego (what Freud called "the Psychic Apparatus"). These are not physical areas within the brain, but rather hypothetical conceptualizations of important mental function. Sigmund Freud assumed the id operated at an unconscious level according to the pleasure principle (gratification from satisfying basic instincts). The id comprises two kinds of biological instincts (or drives) which Freud called Eros and Thanatos. Eros, or life instinct helps the individual to survive; it directs lifesustaining activities such as respiration, eating and sex. The energy created by the life instincts is known as libido. In contrast, Thanatos or death instinct, is viewed as a set of destructive forces present in all human beings. When this energy is directed outward onto others, it is expressed as aggression and violence. Freud believed that Eros is stronger than Thanatos, thus enabling people to survive rather than self-destruct. The ego develops from the id during infancy. The ego's goal is to satisfy the demands of the id in a safe a socially acceptable way. In contrast to the id the ego follows the reality principle as it operates in both the conscious and unconscious mind. The superego develops during early childhood (when the child identifies with the same sex parent) and is responsible for ensuring moral standards are followed. The superego operates on the morality principle and motivates us to behave in a socially responsible and acceptable manner. The basic dilemma of all human existence is that each element of the psychic apparatus makes demands upon us that are incompatible with the other two. Inner conflict is inevitable.

Oppression refers to relation of domination and exploitation-economic, social and psychology between individuals; between social groups and classes within and beyond societies; and globally, between entire societies. Injustice refers to discriminatory, dehumanizing, and development inhibiting conditions of living (e.g., unemployment, poverty, homeless, andlack of health care), imposed by oppressors upon dominated and exploited individuals, social groups, classes and peoples. These conditions will often cause people to turn to social servises for help. Oppression seems motivated by an intent to exploit (i.e., benefit disproportionately from the resources, capacities, and productivity 
of others) and it results typically in disadvantageous, unjust conditions of living for its victims. It servers as a means to enforce expoitation toward the goal of securing

\section{METHOD OF THE RESEARCH}

In collecting the data, the writer uses library research. This research is oriented in the library in order to find the related data, however it is not restricted in finding other written material from internet or even from the motion picture.

According to Pradopo (2001:23), library research refers to the observation that is executed in the library, which the writer gains the data and information about his object through the drama A Doll House.

In analyzing the data, the information from data collection is process and presented in form of thesis. In the application, the writer uses Dynamic Structuralism method. Structural analysis is mainly concerned with finding out the behavior of a physical structure when subjectsd to force. This action can be in the from of load due to the weight of things such as people, furniture, wind, snow, etc, or some other kind of excitation such as an earthquake, shaking of the ground due to a blast nearby, etc. In essence all these loads are dynamic, including the self weight of the structure because at some point in time these loads were not there. The distinction is made between the dynamic and the static analysis on the basic of whether the applied action has enough acceleration in comparison to the structure's natural frequency. If a load is applied sufficiently slowly, the inertia forces (Newton's first law of motion) can be ignored and the analysis can be simplified as static analysis. Structural Dynamic is atype of structural analysis which covers the behavior of structures subjected to dynamic (action having hight acceleration) loading. Dynamic loads include people, wind, waves, traffic, earthquakes, and blasts. Any structure can be subjected to dynamic loading. Dynamic analysis can be used to find dynamic displacements, time history, and modal analysis. A dynamic analysis is also related to the inertia forces developed by a structure when it is excited by means of dynamic applied suddenly (e.g., wind blasts, explosion, earthquake). A static load is one which varies very slowly. A dynamic load is one which changes with time fairly quickly in comparison to the structure's natural frequency. If it changes slowly, the structure's response may be determined with static analysis, but if it varies quickly (relative to the structure's ability to respond), the response must be determind with a dynamic analysis. Dynamic analysis for simple structures can be carried out manually, but for complex structures finite element analysis can be used to calculate the mode shapes and frequencies. Technique is a means of procedure especially a regular and systematic way of completing anything ( the American Herritage Dictionary, Volume fourth:826) additionally according to longman dictionary, of contemporary English Technique is way of work doing something ( Quirk, 1987:681). Technique also means that is a way of work in understanding the object and objective of the science involved with. The qualitative technique has four characteristics, namely : (1) Natural setting is data resources and research of a key instrument (2) The qualitative technique descriptively, means that the data is explained in it (3) The from of word or picture is not statistic (4) The qualitative is considered as more important to process that result. The data analyzing procedures concern with the way of the writer to conduct the analysis of the data. This analysis uses Genetic Structuralism, it looks the external factor of the literature that coveys the internal element of literary work such the actions of the main character, such as characters and author.

Pradopo (2001:54),4 state that
"Penelitian kertugas
menjelaskan karya sastra
sebagai sebuah struktur
berdasarkan unsur-unsur yang
membentuknya seperti
masyarakat dan kehidupan
sosial."(The researcher has a
chance to explain literary
work as structure base on the
elements that formed them,
which are society and social
life). From explanation factor
of literature and show the
relation of this internal factor




\begin{abstract}
wich external factor such as sociology.

In the perspective of the society in the 19th century Nora is a type of women are so lucky because her husband was very fond of Nora and obeying all the wishes of Nora. But Nora felt there was pressure from her husband Torvald because Torvald have always called stupid woman as Nora, small birds, and squirrels, and eventually Nora torvald said she will leave the House, and nora said let me find who actually myself and how powerful Nora live life without the help of Torvald and nora finally away from home by leaving a wedding ring and leave the keys with the slamming of the door then nora leave torvald and her children. From the view of social life at the time that in doing nora very wrong because it is so contrary to the
\end{abstract}

norms in force in the 19th century because at that time women only serving husband, take care of the children and be a good mother to her children, as well as the House. Rather than leave the House-husband and kids for the sake of getting the equality between men and women. From the explanation, Structural method has two function which explain the internal factor of literature and show the relaction of this internal factor with the external such as sociology. In the produce of analyzing the data, the primary data is take from drama it self, writer tries to analyze it by using the information based on the drama it self, the writer starts by analyzing some intrinsic element of this drama, after that tries to find extrinsic element which becomes the basic of the problem that will be analyzed.

\section{THE OPPRESSION FREEDOM OF NORA'S CHARACTER IN A DOLL HOUSE}

A major in the play is looking search for identity, especially concerns to women in the nineteenth-century Europe at that time women only at home taking care of the home, taking care of children and obedient at all the rules given by the husband. Nora is one of those women who get pressure from husband. This theme underlies the basic of freedom oppression for Nora Helmer, who has always lived as a "doll" Nora always gets her own husband of oppression ranging from her husband calling Nora as names of animals.

Torvald helmer: come, come, my little song bird mustn't droop her wings. What's this? Can't have a pouty squirrel in the house, you know.( takes out his wallet) Nora, what do you think i have here? (page:2)

Husband of Nora always monitor all eaten by Nora.

Helmer : When did squirrel come home? What are you hiding something in a bag of Nora

Nora : just now (silence) puts the bag of macaroons back in her pocket, wipes her mouth.(page:1)

What will be done by Nora all under the rule of her husband Torvald. To issue money to nora should ask her husband Torvald
Helmer : come, come my little songbird mustn't droop her wings. What's this? Can't have a pouty squirrel in the house, you know. ( takes out his wallet) Nora, what do you think i have here?

Nora : (truns around quickly). Money

Helmer : Here. ( gives her some bills.) don't you think $i$ know christmas is expensive?

Nora : (counting). Ten twenty thirty forty. Thank you, thank you Torvald. ( page:2)

Torvald is a self centered in her house. Torvald controls Nora's life in order can to monitors what and how much she eats, refers to her with demeaning pet names such as "my little spendthrift", and pats her on the head like a puppy. Another important theme is deception. Because nora always treat it like a puppet in his own house so Nora Torvald helmer cheats to eat something.

just now.(puts the bag of
macaroons back in her pocket,
wipes her mouth.) come out here,
Torvald. I want to show you what
i've bought (page: 1 )

Nora lies to her husband about silly things such as sneaking a few forbidden macaroons for herself, but she also harbors a significant secret which, if reveald, could lead to serve consequences. Nora forged a signature to borrow a large sum of money previously, and 
struggling to pay it back without Torvald's permitt, even though the money was ironically borrowed to save her life.

The freedom oppression which ultimately destroy Nora's and Torvald's marriage stem from pride, unrequited love, and betrayal.

Nora has destroyed his marriage to torvald because nora had lies to Torvald, because Nora had dared to borrow money to loan sharks

When your
husband ill, you
came to me to
borrow twelve
hundred dollars
(page:20).

Nora lies to her husband and betrays his trust in part because she love him and wants to please him. Torvald accept cannot his wife's sacrifice in securing the loan that saved his life because, in desperation, she got the money illegaly and if the fact became known, it would be a blow to his pride. When Torvald will not defend his wife, it is the final betrayal of her love, and their marriage does not survive.

Torvald helmer instead of asking for thanks to Nora instead he issued a word that makes Nora disappointed because the struggle that had been done in the Nora against Torvald just waste

Helme : featherbrained woman, blind, incompetent child( page:40)

Helmer : Now you have wrecked my happiness, ruined my future..(page:39)

Doll's House by hendrick ibsen, is play that was written ahead of its time. In this play Ibsen tacles women's rights as a matter of importance. Throughout this time period it was neglected. A Doll house was written during the movement of naturalism, which commonly reflected society. Ibsen acknowledges the fact that in 19th century life the role of the woman was to stay at home, raise the children and attend to her husband. Nora Helmer is the character in A Doll House who plays the 19th women and is portrayed as a victim.

The inferior role of Nora is extremely important to her character. Nora is oppressed by a variety of "tyrannical social conventions. Ibsen in his Doll's House depicts the role of women as subordinate in order to emphasize their role in society. Nora is oppressed by the manipulation from Torvald. Torvald has a very typical relationship with society. $\mathrm{He}$ is a smug bank manager. With his job arrive many responsibilities. He often treats his wife as if she is one of these responsibilities. Torvald is very authorivative and puts his appearance, both social and physical, ahead of his wife that he supposedly loves. Torvald is a man that is worried about his reputation and cares little about his wife's fillings.

Torvald is only thinking of himself and his office only little attention given at his wife Nora

I know and i have your
promise.(over to her).
All right keep your
little christmas secrets
to yourself, Nora
darling. They'll all
come out tonight, i
suppose, when we light
the tree.(page:3)

Even Torvald also say Nora has thrown money to buy something unnecessary according Torvald but for Nora she needed the object

I'm busy! (after a little while he opens the door and looks in, pen in hand.) bought, eh? All that? So little wastrel has been throwing money around again.(page:1)

Nora and Torvald's relationship, on the outside appears to be a happy. Nora is treated like a child in this relationship, but as the play progresses she begins to realize how phony her marriage is Torvald sees Nora's only role as being the subservient and loving wife. He refers to Nora as "my little squirrel"(1), "my little lark" (1) or "spendthrift"(1). To him she is only a possession. Torvald call Nora by pet-names and speaks down to her because he thinks that she is not intelligent and that she cannot think on her own. Whenever she begins to voice an opinion Torvald quikly drops the pet-names and insults her as a women throught comments like "worries that you couldn't possibly help me with," and “ Nora, Nora,just like a women. "(1) Torvald is a typical husband in his society. He denied Nora the right to think and act the way she wished. He required her to act like an imbecile and insisted upon the rightness of his view in all matters.

When a women of that time love as Nora thinks she does nothing else matters. She will sacrifice herself for the family. Her purpose in 
life is to be happy for her husband and children. Nora did not believe that she loved Torvald and was happy. She had a passionate and devoted heart that was willing to do almost anything for her husband. At first she did not understand that these feelings were not reciprocated. Torvald does not want a wife who will challenge him with her own thoughts and actions. The final confrontation between the couple involves more oppression and actions. The final confrontation between the couple involves more oppression by Torvald, but by this time Nora has realized the situation he wishes to maintain. Torvald calls her a "featherbrained women"(15) and " blind, incompetent child" (15) even though she saved his life. Nora expected Torvald to be grateful to her. This does not happen. When torvald says, " Now you have wrecked all my happiness-ruined my future..."(15) and " I'm saved!" (15), Torvald exhibist his self absorbed nature. The fury Nora saw after Torvald's opening of the letter showed Nora a strange man. Someone she had not been wife to someone she did not love. Their marriage is fake and mutually beneficial because of their social status. They are not really in love. Nora says, "Yes. I am beginning to understand everything now". It is now that she can begin to apprehend her forgery was wrong, not because it was illegal but because it was for an unworthy cause. This is when the reader see Nora embark into her transformation of her individuality her new authentic identity. She comes to realize that her whole life has been a lie. She lived her life pretending to be the old Nora continues well after she becomes a new person. When she realizes that responsibilities for herself are more important Nora slams the door on just Torvald but on everything that happened in her past. It took time to evolve into a new persone but after she did she became a person who could not stand to be oppressed by Torvald any longer. Nora says, "I've been your wife-doll here, just as at home I was papa's doll child."(18) Ibsen uses the idea of a "doll" because a doll always maintains the same look, no matter the situation. A doll must do whatever the controller has them do. Dolls are silent and never express opinions or actually accomplish anything without the aid others. This doll is Nora's inauthentic identity.

Her authentic identity is in the process of being built while Torvald calls Nora his "little lark", "little squirrel", and a child. Nora grows even stronger. It is complete and presented to the readers when Nora when she stands up to Torvald and does the opposite of what he wants.
Nora tells Hellmer at the end of play that," I have to try to educate my self. You can't help me with that. I've got to do it alone. And that's why i'm leaving you now"(23). Nora tells Helmer ," .... I'm a human being, no less than you or anyway, I tought to try to become one."(25). She does not tolerate Torvald's condescending tone or allow him to manipulate her any longer. Nora must follow her own convictions now and decide for herself what her life will be in the future. Her rebirth has led to her own independence. Another man will never again control her and she is now free of her controlling husband.

3.2 The Discrimination of Nora's Character In A Doll House

At the beginning of Doll's House, Nora seems completely happy.

Happiness in feeling Nora in the Doll's House at the time Nora well treated by her husband, what Nora would have been given by the husband. Nora looks very happy when Torvald gives her money to buy Christmas supplies

Helmer : come, come my little songbird mustn't droop her wings. What's this? Can't have a pouty squirrel in the house, you know. ( takes out his wallet) Nora, what do you think i have here?

Nora : (truns around quickly). Money

Helmer : Here. ( gives her some bills.) don't you think i know christmas is expensive?

Nora: (counting). Ten twenty thirty forty. Thank you, thank you Torvald. ( page:2)

Nora was very happy after she went shopping for her home needs

(Here's a crown. No keep the change. ( the Porter thanks her, leaves. Nora close the door. She keeps laughing herself as she takes off her coat, etc. She takes a bag of macaroons the door to the study and listens). Yes, he's home. ( Resumes her humming, walks over to the table, right).

She respond affectionately to Torvald's teasing, speaks with excitement about the extra money his new job will provide and takes pleasure in the company of her children and friends. She does not seem to mind her doll like existence which she is coddled, pampered, and patronized. 
As the play progresses, Nora reveals that is not just a "silly girl," as Torvald call her. That she understands the business details related to the debt she incurred taking out a loan to preserve Torvald's health indicates that she is intelligent and possesses capacities beyond mere wifehood. Her description of her years of secret labor undertaken to pay off her debt shows her fierce determination and ambition. Additionally, the fact that she was willing to break the law

Nora is very brave to take a decision even though the decision is against the law Nora does it all for her husband Torvalds, though Nora has dared to break the law Nora never think of his own safety

Nora forgery the signature of his father for the sake of healing her husband Torvald Krogstad : tell me mrs. Helmer do you happen to remember the date of your father's daeath? I mean the exact day of the month

Nora : Daddy dies on september 29.

Krogstad : quite correct. I have ascertained that fact. That's why there is something perculiar about his(takes out a piece of paper), which i can't account for.

Nora : peculiar? How ?i dont understand

Krogstad : it seems very peculiar, mrs Helmer that your father signed this promissory note three days after his death.

Nora : how so? i dont see what

Krogstad : your father died on september 29. Now look he has date his signature october 2. Isn't that odd?

Nora: remains silents

Krogstad : can you explain it?

Nora : is still silent.

Krogstad : I also find it striking that the date and the month and the year are not in your father's handwriting but in a hand $i$ think $i$ recognize. Well, that might be explained. Your father may have forgotten to date his signature and somebody else may have dont it here,, guessing at the date before he had learned of your father's death. That's all right. It's only the signature it self that matters and that is genuine, isn't it, mrs. Helmer ?your father did put his name to this note?

Nora : ( after a brief silence tosses her head back and looks defiantly at him) no, he didn't. I wrote daddy's name.(page: 19,20, and 21)

in order to ensure Torvald's health shows her courage.

Krogstad's blackmail and the trauma that follows do not change Nora's nature; they open her eyes to her unfulfilled and underappreciated potential. "I have been performing tricks for you, Torvald," she says during her climactc confrontation with him. Nora comes to realize that in addition to her literal dancing and singing tricks, she has been putting on a show throughout her marriage. She has pretended to be someone she is not order to fulfill the role that Torvald her father, and society at large have expected of her.

Torvald's severe and selfish reaction after learning of Nora's deception and forgery is the final catalyst for Nora's awakening. But even in the first act, Nora shows that she is not totally unaware that her life is at odds with her true personality. She defies Torvald in small yet meaningful ways by eating macaroons and then lying to him about it for instance. She also swears apparently just for the pleasure she derives from minor rebellion against societal standards. As the drama unfolds and as Nora's awareness of the truth about her life grows her need for rebellion escalates, culminating in her walking out on her husband and children to find independence.

When Hendrick Ibsen Doll's House was first published in 1879 it was a coming of age play that dealt with the lives and anxieties of the bourgeoisie women in Victorian Norway. Feminism is the dominant theme, as Ibsen investigated the tragedy of being born as abourgeoisie female in a society ruled by a partriarchal law. If examined more closely, one can find traces of Marxist Ideology and other schools of thought. The first thing that $\mathrm{i}$ am going to start with is sheddimg light on the feminist attributes that this play is throbbing with 
and try to see it with the eyes of feminist writers like Simone de Beauvoir, Michel Foucault and other feminist writers. The feminist school of thought has brought revolutionary ideas by exposing masculine stereotypes, revaluting women's roles in society, studying women's cultural and historical background, studying female literature, and criticizing social sexist values.

Nora Helmer is the best illustrasion of the illusion women who lives in a society where the male oppresses the female and reduces to a mere doll or plaything. Nora helmer is that doll living in her fake doll house which reinforces the fragile idea Nora Helmer and the other female figures portrayed in Adoll's House are the best of the "second sex" or the "other" that the French revolutionary writer Simon de Beauvoir discussed in her essay, the second sex. De Beauvoir argues that throught history, women has been viewed as a"hindrance or a prison". Aristotles also said," The female is a female by virtue of a certain lack of qualities. We should regard the female nature as afflicted with a natural defectiveness." Women is always depicted as secondary to man. She does not exist as an entity by herself but as the "other".

In her husband's eyes, Nora is nothing but a silly "squirrel", a "little skylark", a "song bird" or a cute "scatterbrain" whose thoughts are nonsensical and typical to any other women's. Since her childhood Nora has been regarded as the "other" by her father. Then, her father handed her to her husband who treated her like a valued possession. This is best depicted by Nora's self realization and awakening towards the end of the play: "When i lived at home with daddy, he fedme all his opinions, untill they became my opinions or if they didn't, i kept quiet about it because i knew he wouldn't have liked it. $\mathrm{He}$ used to call me his dollchild, and he played with me the way i used to play with my dolls. And when daddy handed me over to you. You arraged everything according to your taste and i adapted my taste to yours. Now looking back i feel as if i've lived a beggar's life from hand to mounth."

Ibsen's depiction of the weak and docile woman brings to mind the 18th century revolution of the right of women, that women are taught since their infancy to have the "softness of temper, outward obedience, and scrupulous attention". Once accompanied by the gift of beauty, these attributes will ensure then protection of man. This is echoed very loudly in Torvald's words, "poor little frightened songbird....rest assured; my wings are broad enought to shelter you. How lovely and secure our home Nora. A sanctuary for you. I'll keep you here like a hunted dove i've rescued unhurt from the hawk's talons. For a man there's something intensely reassuring and pleasurable about knowing that he's forgiven his wife and that he's forgive her sincerely with all his heart. It's as if she becomes somehow doubly his possession, as if he's reborn, so that in some way she becomes both his wife and his child." Moreover, Mary Wollstonecraft stresses that man tries to secure the good conduct of a woman by reducing her to a state of innocence and childhood. She state of innocent; but when the epithet is applied to men , or women it is but a civil term of weakness." This is very evident in Torvald treating Nora as a child. He forbids her to eat macaroons; he makes her dance for him, dresses up and recties for him. On the other hand, not only Nora is treated as a sexual objects that her husband fantasizes about. At parties he keeps away and steals glances at her eventually pretending that they're secretly engaged. When it's time to go, he puts her shawl around her shoulders and pretends that she is his young bride. He fantasizes that they are just arriving from their wedding and are alone for the first time together. He is so possessive about her to the extent that he refuses to share Nora with female friends, like Mrs. Linde. Here, Nora becomes what Michel Foucault calls a docile body regulated by the norms of cultural life.

Thus toward the end of the play, Nora realised that it is time that she regained her status as being the "one". As Simone de Beauvoir has stressed, Nora has been taught no to take but to receive. She has gained only what her husband and father has been willing to grant her. In this sense, Nora's domestic life in such a partiarchal society is just a reflection of the middle class women of her time that De Beauvior depicted vividly in her essay.

"They live dispersed among the males, attached through residence, housework, economic condition, and social standing to certain men father or husbands more firmly than they are to other women. If they belong to the bourgeoisie, they feel solidarity with men of that class, not with proletarian women." Nora's biggest fear is her husband hearing that she had forged her father's signature to get the loan, which she needed to travel to Italy. Her motives were absolutely selfless because that trip saved her sick husband's life. Nora knew that the 
revelation would have put her husband's reputation at stake, but she felt deep inside that her husband would sacrifice his reputation to defend her a soon as he came to know that she did that to save his life.

That feeling tormented her to the extent that she contemplated suicide. She is not worth her husband's nobility! She is not even good enough to be a mother! Didn't her husband tell that "all young criminals have had dishonest mothers because it's usually the mother's responsibility"? Despite her great sacrifice driven by her love for her husband, Nora agrees that she is a bad influence on her children. She even decides to isolate herself from her kids and let the nursemaid take care of them fully. We can hear her saying to herself, "corrupt my children. Poison my home. It's not true.it could never be true. "This proves to us Nora is very pleased with her role as the"other".

Yet, the doll house is shattered as well as Nora's illusion. The doll finally recognize that her role has been nothing but the "Other". She is aware that it is she who agreed to the definition of the "One" and the "Other". It's a moment of profound awakening when Nora realizes that her husband values is her reputation and job more than he values his love for her. Torvald's resenment and accusation after knowing about what she had done comes as a blessing in disguise. We hear Torvald telling her, "For all these years, for eight years now, you've been my pried and joy and now I find you're a hypocrite and a liar, and worse, worse than that a criminal! The whole thing is an abyss of ugliness! You ought to be ashamed." Simone de Beauvoir says that if the women seems to be the inessential which never becomes the essential, it is because she herself fails to bring about the change. The harsh reality smacks her in the face; a wave of disillusionment wakes her up. She decides bravely to abandon her family to escape the restrictive confines of the patriarchal society she lives. She is resolved to go uot into the world and gain real experience. She is determined to think out averything for herself and be able to make her own decisions.

After all that has been said, we conclude that the women figure/body in A Doll House is reduced, as Susan Bordo believes, to a "text of culture" on which all cultural aspects of gender difference are reinforced. That is, the female ideology is supported and reinforced by the social structure in which women have little social, political, or economic power. The women figures in A Doll's House are depicted as socially and psychologicall dependent on men in the institution of marriage and motherhood. In addition to Nora, we have the caracter of Mrs. Linde who has forced to break up with her fiance and marry another man who could support her mother and two brothers. We also come across the character of the nurse who had to give up her child conceived the wedlock in order to keep her job.

From different standpoint, one can argue that A Doll House carries some aspect of the Marxist Ideology regarding the conflicts taking place at that time, not only regarding the male and female relationship, but also financial relations. The Helmer household belongs to the bourgeoisie class that wasn't born as aristocrats, but ascended to social and financial wellbing through employment and education. Hence A Doll House portrays the stubborn class pride of saving face and preserving one's reputation. In the play, Torvald Helmer who is bank manager, confesses that one of the reasons that made him fire Krogstad, one of his employess, was that he was a former schoolmate and still insists on calling him by his first name in front of the other employees at the bank. This embarrasses Torvald and makes him uncomfortable. We also have the character of Mrs.Linde who had to marry someone she didn't love in order to escape poverty, and later, after his death, has to work non-stop workdays. She feels all alone and hollow, working for herself. Mrs. Linde is the best example of the working class person who tastes the bitterness of a materialstic life being reduced to the value of a mere commodity and producer of labor power.

Furthermore, it can be debated that the male-female relationship in A Doll's House is based on a Master Slave ideology which Friedrich Hegel, the great Enlightenment theorist started. The relationship between Torvald and Helmer evolves according to a Master-Slave relationship. Hegel argues that the consciousness of one's self as a self cannot be achievedexpect through confrontation with another. Both Nora and her husband Torvald recognized their dependency on each other and that selfconsciousness led to Nora's awakenig in the end. Thus, Nora's character self was made throught the dialectical special interrelationship between her and her husband on one sidde and between her and the patriarchal society on the other. Hegel says that the self"throught supersession, receives back its own self, because by 
superseding its otherness, it again becomes equal to itself; but secondly, it equally gives the other self-consciousness back again to itself, for it saw itself in the other, but superseded this being of itself in the other and thus lets the other again go free." First Nora acknowledges Torvald as her master and she dutifully assumes her role as the slave who is dependent on her master. After the confrontation, Nora realizes the master's dependency on her master. After the confrontation, Nora realizes the master's dependency on her which leads her to supersede him and be free of him.

I also noticed that we can trace the roots of Ibsen's A Doll House in Plato's Allegory of Cave. Nora's life with her husband is sn illusion and their marriage is a masquerade. As she confronts Torvald, she says, "our house has never been anything but a playroom. I have been your dollwife, just as I was dady's doll-child whend $\mathrm{i}$ was at home. My children as well, they've been my dolls. I used to enjoy it when you played games with me, just as they enjoyed it when i played games with them. That's all our marriage has been, Torvald." Thus her life in A Doll House was like the life of the people chained in the cave. What she saw was not the true reality, but the shadow of reality. She was content with her role as the subservient female whose fate was determined position in the relationship. This is evidenced in her complete confidence in hiding the truth about borrowing money in order to save Torvald's health. About that she told Mrs. Linde, "it would be a terrible blow to Torvald's masculine self-esteem; he'd find it so painful and humiliating to thing that he owed me something. It would completely unbalance our relationship. It would be the end of our beautiful, happy home." Thus Nora emerges from that cave that showed her the distortwed reality. Upon realizing her value in her husband's life, the true reality dazzles her like the bright sun. She realizes that she has been living with a stranger for eight years; she becomes aware of the crippling society that she is living in. Therefore, she decides to leave the dark cave and embrace the luminous freedom that she grants herself.

A Doll House is revolutionary play the exposes the defects of the Victorian patriarchal society. It is the triumph of the women over all hindrances whether social, masculine, or economic. Once i finished reading the play, i was left in relective state. I thought about the universalty of the women figure portrayed in
Ibsen's play. Now about 130 years after publication of A Doll House, many women still face the same circumstances that Nora faced. Forinstance, today's women working in the same capacityas men about 72 cents compared to a dollar for men. Aditionally many women face discrimination in the workplace and in life in general.many profession remain dominated by men in a day when women are more than capable of physically handling the job. Despite all their social, political, and career advancement, some women still feel emotionally crippled as their destinies are tied to that of the patriarchal society. The rise in the number of women suffering from anorexia and bulimia nowadays is an evidence of the emotional oppression that women are subjected to Susan Bordo believes that social norms of beauty, motherhood, absence or presence of sexsual modesty position the woman in a struggle with the prevailing social images and conventions.

"I believe that before anything else, I'm a human being, just as much of as you are... or at least I'm going to try to turn my self into one," Nora tells Torvald in a moment of selfrealization. This has been the women's quest throughout history. Nora Helmer in A Doll House triumphs over all obstacles and finally recognizes her duty towards herself which had always been neglected. Yet many more women still continue to shatter the collars of gender anxiety and enslavement placed by the masculine world around their necks.

\subsection{Nora's Right Fighting At That Era In A Doll House}

Play Doll House Nora is very dear to her husband and children. One day Nora knew him only in treats such as stuffed by her husband Torvald but nora did not show the slightest changes on Torvald. He is still the same as it used to be. Once torvald know that Nora has been lying to him very upset to Nora Torvald. Torvald says Nora is a liar.

At that time Nora apologize to her husband Torvald but Torvald not want to forgive Nora, Torvald still just keep blaming Nora. At that moment Nora has taken a decision which he considers to be true. By saying a word that makes Torvalds unable to think clearly at that moment

That's right. Now it is all over. I have put the keys here. The maids know all about everything in the house--better than I do. 


\begin{abstract}
Tomorrow, after I have left her, Christine will come here and pack up my own things that I brought with me from home. I will have them sent after me(page:62)
\end{abstract}

At the same time Nora tells Torvald that Nora will leave Torvald and his children. Torvald said to Nora go from this house i believe without me you can not do anything. On the next day Torvald forgive mistakes Nora but Nora still want to leave torvald. Torvalds tells Nora if a husband is still willing to forgive his wife's mistake then he is still very fond of his wife. But Nora still does not listen to what Torvalds says.

Finally Torvalds said something the word he thinks it can all stop the Nora's departure at the time

Helmer: Before all else, you are a wife and a mother.

Nora: I don't believe that any longer. I believe that before all else I am a reasonable human being, just as you are-or, at all events, that I must try and become one. I know quite well, Torvald, that most people would think you right, and that views of that kind are to be found in books; but I can no longer content myself with what most people say, or with what is found in books. I must think over things for myself and get to understand them.(page:61)

In this play a doll house a woman named Nora married with Torvald from rich family. At the beginning of their marriage look like harmonious couple with no problem at all in their household finally arise a mass that make Nora have to go leave her husband house and her three children.

In the A Doll House Drama Nora fighting for his rights at that time by fighting all the actions of her husband so far who has considered the Nora as a puppet in the house what what Nora should be under the control of her husband Torvald as if Nora feel himself like a child who is always in the protection of people Its old.

In the end Nora
against her
husband torvald
resistance.
Nora: thats the
whole point. You
have never
understood me.
Great wrong has
been done to me,
Torvald. First by
daddy and then
by you.(page: 59

The last resistance that Nora did to Torvalds at the time by leaving Torvalds and his three children

That's right. Now it is all over. I have put the keys here. The maids know all about everything in the house--better than I do. Tomorrow, after I have left her, Christine will come here and pack up my own things that I brought with me from home. I will have them sent after me(page:62)

Before nora gone she has left her marriage to torvald ring while slamming the door. The last speech in utter nora to torvald That our life together would be a real wedlock. Goodbye (page:63)

The conclusion on the drama doll house how to Nora fighting for his rights is to leave the house and leave his husband and three children. Without expecting help from her husband again. Nora sure without her husband Nora can fight for his own life. 


\section{CONCLUSIONS AND SUGESSTIONS}

This chapter presents the conclusions of the study, which are based on the findings and discussion in the previous chapter.

The freedom oppression which ultimately destroy Nora's and Torvald's marriage steam from pride, unrequited love, and betrayal.

The discrimination at the beginning of $\mathrm{A}$ Doll House, Nora seems completely happy. She responds affectionately to Torvald's teasing, speaking with excitement about the extra money her new job will provide, and takes pleasure in the company of her children and friends. She does not seem to mind her doll-like existence, in which she is coddled, pampered, and patronized.

In order to fight for her rights a woman Nora willing to leave her husband and children. Regardless of what Torvald's said to him. In fighting for his rights Nora's willingly sacrificed all including his marriage and those in his unfortunately.

\subsection{SUGESSTIONS}

The writer hopes this thesis analysis may at least add the vocabulary of literary study in which may be useful for students of literature later on. That is why this thesis analysis is open for further study its weakness. However, the analysis it offers has given the notion that is better to try than to do nothing. The writer hopes this thesis may encourage students of literature to make vigorous research in literary works.

And the thing I like most about in the Doll's House drama is how the Nora struggle to defend its right at that time even though it is very contrary to the law at that time. If there is no resistance from Nora's maybe at this moment we still feel the oppression of freedom by the men. 


\section{Bibliography}

Daiches, David. 1990. Critical approaches to Literatur, Singapore: Singapore Publisher Ltd.

Ferguson, Robert. 2001. Henrik Ibsen : A New Biography. Dorset First Edition Thus edition

Freud, Sigmund. 1956. The resistances to psychoanalysis. Standard Edition of the Complete Psychological Works of Sigmund Freud. The Ego and the Id and Superego.

Gil, D. G.(1994). Confornting social injustice and oppression. In F. G. Reamer (Ed.), The foundations of social work knowledge. New York: Columbia.

Hadi, Sutrisno. 1995. Metodologi Research, Yogyakarta: Andi Osffset.

Markman, Roberta H. et al. 1982. 10 steps in writing the research paper, New York: Barron's Educational Series Inc.

Pradopo, Rahmat Djoko. et al. 2001. Metodologi
Penelitian Sastra. Yogyakarta: PT. Hanindita Graha Widya.

Pradopo, Rahmat Djoko. 2001. Metode Analisis Data. Yogyakarta: PT. Hanindita Graha Widya.

Pradopo, Rahmat Djoko. 2001. Tinjauan Pustaka. Yogyakarta: PT. Hanindita Graha Widya.

Quirk ,R. 1987 . Longman Dictionary of Contemporary English. London : Longman

Sternberg, R. J. 1996. A Triangular Theory of Love. Psychological Review, 93(2). Brace and World Inc.

Wiyatmi. 2012. Kritik Sastra Feminisme: Teori dan Aplikasinya dalam Sastra Indonesia. Yogyakarta: Penerbit Ombak.

Wellek, Rene and Austin Warren. 1996. Theory and Literature, New Harcourt Brace and World Inc. 